\title{
Manajemen Strategik Kepemimpinan Dalam Meningkatkan Kualitas Guru SMP di Kabupaten Karawang
}

\author{
Abduloh$^{1}$, Bambang Ismaya ${ }^{2}$ \\ ${ }_{1,2}$ Prodi Pendidikan Jasmani Kesehatan dan Rekreasi, Universitas Singaperbangsa Karawang
}

\begin{tabular}{l} 
ARTICLE INFO \\
\hline Article History: \\
Received 17.01.2018 \\
Received in revised \\
form 12.02.2018 \\
Accepted 21.03.2018 \\
Available online \\
16.04.2018
\end{tabular}

\begin{abstract}
Education at the secondary level is a first step in a journey of a protege life where this is a serious thing in a management of an educational institution at the junior level (SMP). Therefore an education at junior level requires a competitive leadership quality in being able to build a new strategy in improving teacher quality. If observed the quality of junior high school teachers in Karawang regency in particular requires a freshness in an education management process, where every educational institution requires a leader figure who can improve the teachers quality. Thus, a school leader must have a strategic in managing teachers and staff. So this study aims to determine the extent to which strategic management has been done in improving the quality of junior high school teachers in Karawang. Research method used is descriptive qualitative. The research was conducted on the leader in junior high school in Karawang regency, with research time from March to December 2015. While in the preparation of this study, the authors take field research where to obtain accurate and objective data, the researchers come directly to the location of research that is in Karawang regency.
\end{abstract}

Keywords:

Leadership Strategy Management, SMP Leaders, Teacher Quality.

DOI: $10.30653 / 003.201841 .41$

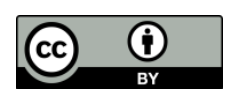

This is an open access article distributed under the terms of the Creative Commons Attribution 4.0 International License, which permits unrestricted use, distribution, and reproduction in any medium, provided the original work is properly cited. @ 2018 Abduloh, Bambang Ismaya.

\section{PENDAHULUAN}

Kegiatan pendidikan yang berkualitas mensyaratkan pada adanya faktor kepemimpinan yang kuat. Tanpa adanya faktor kepemimpinan yang kuat dan melibatkan banyak faktor akan mengakibatkan proses pendidikan kehilangan visinya dan bergerak seolah tanpa arah. Hal tersebut pada gilirannya akan berakibat pada ineffectivity dimana berbagai biaya yang telah dikeluarkan akan menguap begitu saja tanpa ada hasil yang dapat mempertanggungjawabkan. Pemikiran tersebut merupakan landasan bagi pentingnya kepemimpinan dalam pendidikan (Fainstein \& Canbell, 2002; Bush, 2003; Bush \& Middlewood, 2013).

Kegiatan pendidikan yang struktur, sistematis dan memiliki tujuan yang jelas hanya ada disekolah sebagai muara pendidikan semua negara dari dulu sampai sekarang. Sekolah merupakan salah salah satu sarana untuk membangun masyarakat. Sekolah juga dapat dikatakan sebagai agen perubahan masyrakat, baik lokal, regional maupun global. Manusia Indonesia yang diharapkan

${ }^{1}$ Corresponding author's address: Universitas Singaperbangsa, Karawang, Indonesia e-mail: abduloh175@gmail.com 
saat ini adalah manusia yang mampu mengembangkan keseluruhan potensi yang yang dimilikinya. Gambaran manuia Indonesia yang seutuhnya tersebut telah dirumuskan didalam undang-undang RI Nomor 20 tahun 2003 tentang Sistem Pendidikan Nasional pasal 3 yang menyatakan bahwa Pendidikan Nasional bertujuan untuk berkembangnya potensi peserta didik agar menjadi manusia yang beriman bertaqwa kepada Tuhan Yang Maha Esa, berakhlak mulia, sehat, berilmu, cakap, kreatif, mandiri, dan menjadi warga negara yang demokratis serta bertanggungjawab. Hal tersebut sesuai dengan visi Kementrian Pendidikan dan Kebudayaan (2010) yang tertuang dalam renstra 2005-2025, yakni "Terselenggaranya Layanan Prima Pendidikan Nasional untuk Membentuk Insan Indonesia Cerdas Komprehensif'. Dan pada tahun 2025 mendatang, rencana strategis tersebut diarahkan pada penguatan daya saing internasional. Ini berarti bahwa negeri ini sedang menyiapkan sumberdaya manusianya agar mampu bersaing di dunia global. Untuk menuju kearah tersebut, peningkatan mutu sekolah menjadi sine quanone, suatu hal yang tidak bisa ditawar lagi.

Oleh karena itu bagi setiap pemimpin sekolah harus mempunyai manajemen Strategik dalam meningkatkan kualitas guru didalam proses pengajaran dan pembelajarannya. Maka dihrapakan pemimipin-pemimpin sekolah SMP di Karawang harus mampu meningkatkan kualitas gurugurunya didalam proses belajar mengajarnya, sehingga di harapkan akan meningkatkan kualitas peserta didik yang mampu bersaing di tingakat Nasional maupun Internasional. Untuk Membentuk kualitas pendidikan SMP yang mampu bersaing di dunia Nasional maupun Internasioanl dapat dianalisis berdasarkan beberapa faktor. Faktor-faktor tersebut antara lain adalah bagaimana manajemen Strategik Kepemimpin sekolah SMP dalam meningkatkan kualitas guru tersebut: 1) Peran dan fungsi seorang pemimpin sekolah; 2) Manajemen Strategik kepemimpinan sekolah; dan 3) Peran partisipasi guru.

\section{METODE}

Pada penelitian ini digunakan metode observasi yang bertujuan untuk mengamati, melihat dan mengumpulkan data secara sistematis terhadap obyek penelitian, selain itu digunakan pula metode wawancara kepada 20 responden yang terdiri dari pimpinan sekolah (kepala sekolah) dan pendidik (guru) sebagai sumber belajar yang tersebar di SMP-SMP, baik negeri maupun swasta di Kabupaten Karawang, sehingga hasil penelitian menggambarkan pelaksanaan manajemen strategik dalam meningkatkan mutu peran dan fungsi guru di Kabupaten Karawang.

\section{HASIL DAN PEMBAHASAN}

Hasil observasi dan wawancara dengan responden, dalam hal ini yang menjadi responden adalah Kepala Sekolah dan pendidik/sumber belajar yang melaksanakan manajemen Strategik di dalam meningkatkan mutu peran dan fungsi guru di Kabupaten Karawang yakni sebagai berikut.

\section{Peran dan Fungsi Pemimpin Sekolah dalam Meningkatkan Kualitas Guru di SMP}

Berdasarkan hasil penelitian dari 15 Responden, sebanyak lima (5) Responden menyebut secara umum bahwa peran dan fungsi pemimpin sekolah di SMP dalam meningkatkan kualitas guru di Kabupaten Karawang, dapat mengetahui dan memahami walau masih sebagian kecil di beberapa sekolah, pimpinan sekolah belum berperan dan berfungsi secara maksimal, karena masih ada beberapa kepala sekolah memiliki jabatan rangkap, dan adanya keterbatasan sumberdaya yang belum memadai menurut. Sebanyak 10 Responden menguraikan bahwa peran pimpinan sekolah harus dapat berfungsi sebagai:

1) Pemimpin sekolah sebagai Educator (Pendidik) kegiatan belajar mengajar merupakan inti dari proses pendidikan dan guru merupakan pelaksana dan pengembang utama kurikulum di sekolah. Kepala sekolah yang menunjukkan komitmen tinggi dan fokus terhadap pengembangan kurikulum dan kegiatan belajar mengajar di sekolahnya tentu saja akan sangat memperhatikan tingkat kompetensi yang dimiliki gurunya, sekaligus juga akan senantiasa berusaha memfasilitasi dan mendorong agar para guru dapat secara terus menerus 
meningkatkan kompetensinya, sehingga kegiatan belajar mengajar dapat berjalan efektif dan efisien sesuai dengan rencana yang telah ditetapkan.

2) Pemimpin sekolah Sebagai Manajer dalam mengelola tenaga kependidikan, salah satu tugas yang harus dilakukan kepala sekolah adalah melaksanakan kegiatan pemeliharaan dan pengembangan profesi para guru. Dalam hal ini, kepala sekolah seyogyanya dapat memfasiltasi dan memberikan kesempatan yang luas kepada para guru untuk dapat melaksanakan kegiatan pengembangan profesi melalui berbagai kegiatan pendidikan dan pelatihan, baik yang dilaksanakan di sekolah, seperti: MGMP/MGP tingkat sekolah, atau melalui kegiatan pendidikan dan pelatihan di luar sekolah, seperti kesempatan melanjutkan pendidikan atau mengikuti berbagai kegiatan pelatihan yang diselenggarakan pihak lain.

3) Pemimpin sekolah sebagai Administrator khususnya berkenaan dengan pengelolaan keuangan, bahwa untuk tercapainya peningkatan kompetensi guru tidak lepas dari faktor biaya. Seberapa besar sekolah dapat mengalokasikan anggaran peningkatan kompetensi guru tentunya akan mempengaruhi terhadap tingkat kompetensi para gurunya. Oleh karena itu kepala sekolah seyogyanya dapat mengalokasikan anggaran yang memadai bagi upaya peningkatan kompetensi guru.

4) Pemimpin Sekolah Sebagai Supervisor untuk mengetahui sejauh mana guru mampu melaksanakan pembelajaran, secara berkala kepala sekolah perlu melaksanakan kegiatan supervisi, yang dapat dilakukan melalui kegiatan kunjungan kelas untuk mengamati proses pembelajaran secara langsung, terutama dalam pemilihan dan penggunaan metode, media yang digunakan dan keterlibatan siswa dalam proses pembelajaran. Dari hasil supervisi ini, dapat diketahui kelemahan sekaligus keunggulan guru dalam melaksanakan pembelajaran, tingkat penguasaan kompetensi guru yang bersangkutan, selanjutnya diupayakan solusi, pembinaan dan tindak lanjut tertentu sehingga guru dapat memperbaiki kekurangan yang ada sekaligus mempertahankan keunggulannya dalam melaksanakan pembelajaran. Sebagaimana disampaikan oleh Sudarwan Danim mengemukakan bahwa menghadapi kurikulum yang berisi perubahan-perubahan yang cukup besar dalam tujuan, isi, metode dan evaluasi pengajarannya, sudah sewajarnya kalau para guru mengharapkan saran dan bimbingan dari kepala sekolah mereka. Dari ungkapan ini, mengandung makna bahwa kepala sekolah harus betul-betul menguasai tentang kurikulum sekolah. Mustahil seorang kepala sekolah dapat memberikan saran dan bimbingan kepada guru, sementara dia sendiri tidak menguasainya dengan baik.

5) Pimpinan sekolah sebagai Leader (Pemimpin) Gaya kepemimpinan kepala sekolah seperti apakah yang dapat menumbuh-suburkan kreativitas sekaligus dapat mendorong terhadap peningkatan kompetensi guru. Dalam teori kepemimpinan setidaknya kita mengenal dua gaya kepemimpinan yaitu kepemimpinan yang berorientasi pada tugas dan kepemimpinan yang berorientasi pada manusia. Dalam rangka meningkatkan kompetensi guru, seorang kepala sekolah dapat menerapkan kedua gaya kepemimpinan tersebut secara tepat dan fleksibel, disesuaikan dengan kondisi dan kebutuhan yang ada. Mulyasa menyebutkan kepemimpinan seseorang sangat berkaitan dengan kepribadian, dan kepribadian kepala sekolah sebagai pemimpin akan tercermin sifat-sifat sebagai barikut: (1) jujur; (2) percaya diri; (3) tanggung jawab; (4) berani mengambil resiko dan keputusan; (5) berjiwa besar; (6) emosi yang stabil, dan (7) teladan.

6) Pimpinan sekolah Sebagai Inovator dalam rangka melakukan peran dan fungsinya sebagai innovator, kepala sekolah harus memiliki strategi yang tepat untuk menjalin hubungan yang harmonis dengan lingkungan, mencari gagasan baru, mengintegrasikan setiap kegiatan, memberikan teladan kepada seluruh tenaga kependidikan sekolah, dan mengembangkan model model pembelajaran yang inofatif. Kepala sekolah sebagai inovator akan tercermin dari cara cara ia melakukan pekerjaannya secara konstruktif, kreatif, delegatif, integratif, rasional, objektif, pragmatis, keteladanan 
7) Pimpinan sekolah sebagai Motivator harus memiliki strategi yang tepat untuk memberikan motivasi tenaga kependidikan dalam melaksanakan tugas dan fungsinya. Motivasi ini dapat ditumbuhkan melalui pengaturan lingkungan fisik, pengaturan suasana kerja, disiplin, dorongan, penghargaan secara efektif, dan penyediaan berbagai sumber belajar melalui pengembangan Pusat Sumber Belajar (PSB).

8) Pimpinan sekolah sebagai entrepreneur yang artinya dalam penerapan prinsip-prinsip managerial pendidikan dihubungkan dengan kewirausahaan agar dapat meningkatkan kopetensi guru dan dapat memanfaatkan bergai peluang yang ada di lingkungan sekolah untuk menjadi bahan dan sumber yang dapat menunjang penyelenggaraan pendidikan.

Selanjutnya mengenai fungsi pimpinan sekolah dalam meningkatkan mutu dan kualitas pendidikan menurut pendapat 14 Responden, bahwa kepala sekolah sebagai pemimpin harus mampu berperan sebagai berikut:

1) Pelaksana (executive) yang artinya seorang pemimpin tidak boleh memaksakan kehendak sendiri terhadap kelompoknya. Ia harus berusaha memenuhi kehendak dan kebutuhan kelompoknya, juga program atau rencana yang telah ditetapkan bersama

2) Perencana (planner) sebagai pemimpin sekolah dapat membuat dan menyusun perencanaan, sehingga segala sesuatu yang akan diperbuatnya bukan secara sembarangan saja, tatapi segala tindakan diperhitungkan dan bertujuan.

3) Seorang ahli (expert) seorang pemimpin sekolah dapat memiliki keahlian terutama yang berhubungan dengan tugas jabatan kepemimpinan yang dipegangnya.

4) Mengawasi hubungan antara anggota-anggota kelompok (contoller of internal relationship) menjaga jangan sampai terjadi perselisihan dan berusaha mambangun hubungan yang harmonis.

5) Mewakili kelompok (group representative) ia harus menyadari, bahwa baik buruk tindakannya di luar kelompoknya mencerminkan baik buruk kelompok yang dipimpinnya.

6) Bertindak sebagai pemberi ganjaran / pujian dan hukuman.ia harus membesarkan hati anggotaanggota yang bekerja dan banyak sumbangan terhadap kelompoknya.

7) Bertindak sebagai wasit dan penengah (arbitrator and mediator) dalam menyelesaikan perselisihan atau menerima pengaduan antara anggota-anggotanya ia harus dapat bertindak tegas, tidak pilih kasih atau mementingkan salah satu anggotanya.

8) Pemegang tanggung jawab para anggota kelompoknya ia haruslah bertanggung jawab terhadap perbuatan-perbuatan anggota-anggotanya yang dilakukan atas nama kelompoknya.

9) Sebagai pencipta/memiliki cita-cita (ideologis) seorang pemimpin hendaknya mempunyai kosepsi yang baik dan realistis, sehingga dalam menjalankan kepemimpinannya mempunyai garis yang tegas menuju kearah yang dicita-citakan.

10) Bertindak sebagai ayah (father figure) tindakan pemimpin terhadap anak buah/kelompoknya hendaknya mencerminkan tindakan seorang ayah terhadap anak buahnya.

Selanjutnya yang berhubungan dengan tugas pemimpin sekolah menurut sembilan (9) Responden mencakup dua hal, yaitu bidang administrasi dan bidang administrasi yang meliputi:

1) Pengelolaan pengajaran, ini merupakan dasar kegiatan dalam melaksanakan tugas pokok. Kegiatan yang berhubungan dengan pengelolaan sebagai berikut: a) Pemimpin sekolah sebagai pemimpin pendidikan hendaknya menguasai garis-garis besar program pengajaran untuk tiap bidang studi dan tiap kelas, b) Pemimpin sekolah dapat menyusun program sekolah minimal untuk satu tahun, c) Menyusun kalender pendidikan dan jadwal pelajaran, d) Mengkoordinir kegiatan-kegiatan penyusunan model satuan pengajaran, e) Mengatur kegiatan penilaian, f) Melaksanakan norma-norma kenaikan kelas, g) Mencatat dan melaporkan hasil kemampuan belajar siswa, h) Mengkoordinir kegiatan bimbingan sekolah, i) Mengkoordinir program non kurikuler, j) Merencanakan pengadaan, k) Memelihara dan mengembangkan buku perpustakaan sekolah dan alat-alat pelajaran.

2) Pengelolaan kepegawaian, termasuk dalam bidang ini yaitu menyelenggarakan urusan-urusan yang berhubungan dengan penyeleksian, pengangkatan kenaikan pangkat, cuti, perpindahan 
dan pemberhentian anggota staf sekolah, pembagian tugas-tugas di kalangan anggota staf sekolah, masalah jaminan kesehatan dan ekonomi, penciptaan hubungan kerja yang tepat dan menyenangkan, masalah penerapan kode etik jabatan.

3) Pengelolaan kesiswaan, dalam bidang ini kegiatan yang nampak adalah perencanaan dan penyelenggaran siswa baru, pembagian siswa atas tingkat-tingkat, kelas-kelas atau kelompokkelompok (grouping), perpindahan dan keluar masuknya siswa-siswa (mutasi), penyelenggaraan pelayanan khusus (special services) bagi siswa, mengatur penyelenggaraan dan aktivitas pengajaran, penyelenggaran testing dan kegiatan evaluasi, mempersiapkan laporan tentang kemajuan masalah disiplin siswa, pengaturan organisasi siswa, masalah absensi, dan sebagainya.

4) Pengelolaan gedung dan halaman, pengelolaan ini menyangkut usaha-usaha perencanaan dan pengadaan, inventarisasi, pengaturan pemakaian, pemeliharaan, rehabilitasi perlengkapan dan alat-alat material sekolah, keindahan serta kebersihan umum, usaha melengkapi yang berupa antara lain gedung (ruangan sekolah), lapangan tempat bermain, kebun dan halaman sekolah, meubel sekolah, alat-alat pelajaran klasikal dan alat peraga, perpustakaan sekolah, alat-alat permainan dan rekreasi, fasilitas pemeliharaan sekolah, perlengkapan bagi penyelenggaraan khusus, transportasi sekolah, dan alat-alat komunikasi,

5) Pengelolaan keuangan, dalam bidang ini menyangkut masalah-masalah urusa gaji guru-guru dan staf sekolah, urusan penyelenggaraan otorisasi sekolah, urusan uang sekolah dan uang alatalat siswa-siswa, usaha-usaha penyediaan biaya bagi penyelenggaraan pertemuan dan perayaan serta keramaian.

6) Pengelolaan hubungan sekolah, dan masyarakat untuk memperoleh simpati dan bantuan dari masyarakat termasuk orang tua siswa-siswa, dan untuk dapat menciptakan kerjasama antara sekolah, rumah, dan lembaga-lembaga sosial.

Kemudian menurut 13 Responden bahwa pimpinan sekolah dapat berwenang untuk mengambil tindakan dan keputusan sebagai berikut:

1) Memberikan atau mendelegasikan tugas dan kewajibannya kepada bawahannya apabila berhalangan dan tidak dapat menjalankan tugasnya sebagai mana mestinya.

2) Mengendalikan system manajemen mutu sekolah.

3) Mengangkat dan memberhentikan dalam unit kerja wakil kepala sekolah

4) Memberikan teguran, sanksi bagi pegawai yang melanggar ketentuan disiplin dan tata tertib.

5) Menandatangani surat-surat dinas dan surat berharga lainnya, yang berhubungan dengan manajemen sekolah.

Berhubungan dengan tugas pimpinan sekolah yang sering dilakukan kepala sekolah di kabupaten Karawang menurut hasil wawancara, sebanyak 11 Responden menyebut bahwa kepala sekolah memiliki tugas sebagai berikut:

1) Pengelola dan pengkoordinir kegiatan para wakil kepala sekolah, Kepala TU, para Pembina PKS, pembantu kepala sekolah seluruh bidang.

2) Memimpin dan membina personil guru dan seluruh pegawai atau karyawan sekolah.

3) Meyusun dan merencanakan RAPBS(Rencana Anggaran Pendapatan dan Biaya sekolah.

4) Menyelenggarakan rapat koordinasi dan tinjauan manajemen sekolah keluruh unit pelaksana program kegiatan sekolah.

Berdasarkan uraian diatas bahwa gambaran umum peran dan fungsi pemimpin sekolah di SMP dalam meningkatkan kualitas guru di Kabupaten Karawang memiliki kompetensi yang sesuai dengan permendiknas No13 Tahun 2007 tentang standar kepala sekolah yaitu kompetensi Manajerial, Kompetensi Kewirausahaan, Kompetensi Supervisi Kompetensi Sosial, kompetensi, dan Kepribadian.

\section{Upaya Manajemen Strategik Kepemimpinan Meningkatkan Kualitas Guru SMP}

Dari hasil wawancara dengan Para kepala sekolah sebagai sample penelitian: Menurut 11 Responden bahwa upaya meningkatkan kualitas guru SMP di Kabupaten Karawang belum dapat 
dilaksanakan dan diselenggarakan diseluruh sekolah dengan secara efektif dan efisien. 8 Responden menyebut karena letak georafis wilayah Kabupaten Karawang dan medan yang beraneka ragam masih terdapat kendala diantaranya, adanya keterbatasan sumber tenaga, biaya dan sarana dan fasilitas belum memadai. Tetapi parakepala sekolah berupaya membuat program dan membuat terobosan-terobosan untuk meningkatkan mutu guru dengan melalui pembinaan, MGMP, (Musyawarah Guru Mata Pelajaran) Program Guru berprestasi, Program Beasiswa pendidikan dan latihan melalui MKKS (Musyawarah Komisariat Kepala Sekolah). Mengusulkan program penyediaan sarana fasilitas, dana operasional kepada pemeritahan daerah baik anggaran APBD maupun APBN melalui Dinas Pendidikan Kabupaten Karawang, serta bekerja sama dengan dinas instansi lainya yang dapat menjadi donatur dan mendukung program kegiatan pendidikan. Menurut 5 Responden dalam setiap upaya perencanaan program pembinaan, pendidikan dan pelatihan para kepala sekolah melakukan anilisis tujuan dan analiis kebutuhuan sekolah agar dapat menentukan target, sasaran yang akan dicapai, dengan secara efektivitas dan efesiensi. Maka untuk itu kepala sekolah berupaya menyusun suatu rencana upaya yaitu dengan menyusun strategik agar dapat mencapai tujuan yang telah direncanakan dengan secara cepat dan tepat mencapai sasaran yang telah ditetapkan dengan kegiatan langkah-langkah meliputi 1). menentukan tujuan dan sasaran tujuan program, 2) mengidentifikasi dan menanalisis,kebutuhan program baik dalam lingkungan organisasi sekolah dan luar lingkungan organisasi sekolah, 3) menyusun rencana pelaksanaan alternatif program,4) melaksanakan alternatif program, dan 5) evaluasi program.

Sebanyak 12 Responden menggambarkan bahwa upaya pimpinan sekolah untuk mencari sumber dana, menyediakan tenaga ahli, melengkapi sarana dan prasarana, yaitu dengan mengusulkan kepada pemerintahan daerah dan pusat dengan penganggaran di daerah (APBD) dan anggaran negara (APBN) melalui dinas pendidikan, dan juga bekerja sama dengan dinas instansi lainnya serta pihak swasta yang bersedia untuk menjadi donatur penyelenggaraan pendidikan.

Berdasarkan uraian tersebut diatas dapat disimpulkan bahwa Upaya manajemen Strategik kepemimpinan meningkatkan kualitas guru SMP di Kabupaten Karawang. Para pimpinan sekolah melakukan upaya untuk meningkatkan kualitas guru yaitu dengan membuat rencana, dan program pendidikan, pembinaan, pelatihan dan pendidikan guru, melalui, program beasisiswa untuk melanjutkan pendidikan guru, program pembinaan melalui program seminar dan diklat karya ilmiah melalui MGMP (Musyawarah Guru Mata Pelajaran) dan MKKS(Musyawarah Kelompok Kerja Sekolah), dan kerjasama dengan LPMP (lembaga penjamin Mutu Pendidikan) dengan Program Anggaran dari APBD(Anggaran Pendapatan Belanja Daerah dan APBN (Anggaran Pendapatan Belaja Negara), dengan melakukan langkah-langkah: 1) menentukan tujuan dan sasaran tujuan program; 2) mengidentifikasi dan menganalisis, kebutuhan program;3) menyusun rencana pelaksanaan alternatif program; 4) melaksanakan alternatif program, dan 5) evaluasi program.

\section{Peran dan partisipasi guru dalam meningkatkan kualitas pendidikan di SMP}

Dari hasil wawancara peran guru dalam meningkatkan kualitas guru dapat memiliki berperan apabila seorang guru dapat merencanakan kegiatan pembelajaran, melaksanakan pembelajaran menevaluasi kegiatan pembelajaran dan melakukan tindakan perbaikan mutu hasil belajar siswa. Menurut 12 Responden, mampu membuat dan melaksanakan administrasi kegiatan proses pembelajaran, guru dapat menggerakan siswa untuk melakukan pembelajaran juga dapat mempasilitasi minat dan bakat siswa serta dapat menilai dan mengevaluasi kegiatan proses pembelajran sesuai dengan Undang Undang No. 20 Tahun 2003 dan Undang Undang No. 14 Tahun 2005 peran guru adalah sebagai pendidik, pengajar, pembimbing, pengarah, pelatih, penilai dan pengevaluasi dari peserta didiknya

Kemudian yang berkaitan dengan partisipasi guru dalam meningkatkan kulitas pendidikan di tingkat SMP di kabupaten Karawang, menurut 11 Responden: RB1, RB2, RB3, RB4, RB5, RB10, RB11, RB12, RB,13, RB,14, dan RB15 mengemukakan bahwa tingkat partisipasi guru dalam meningkatkan Kualitas pendidikan di kabupaten karawang belum maksimal karena masih ada beberapa sekolah 
mengalami keterbatasan sarana, biaya dan keterbatasan guru terutama sekolah-sekolah yang berada di daerah pedesaan.

Selanjutnya secara umum guru di tingkat SMP di kabupaten karawang dapat memahami dan mengerti tentang fungsi dan pelaksanaanya guru dalam meningkatkan kualitas pendidikan di tingkat SMP di kabupaten Karawang berdasarkan wawacara, menyebut bahwa fungsi guru adalah sebagai manajer kelas, administrator, Inisiator, inspirator, motivator, fasilitator, transpormator, evaluator, korektor, Inovator dan lainya walau semua fungsi tersebut belum dapat dilaksanakan dengan secara optimal kareana ada penyebab lain yang tidak dapat diprediksi dan belum memadai diantaranya, tidak berjalannya menajemen sekolah, kurangnya sarana dan pasilitas yang memadai, kurangnya sumber dana dan terbatasnaya tenaga ahli dalam bidang keterampilan khusus.

Kemudian secara umum guru SMP di Kabupaten Karawang memahami dan mengerti mengenai tugasnya sebagai guru dalam meningkatkan kulitas pendidikan di tingkat SMP di kabupaten Karawang, berdasarkan hasil wawancara menyebutkan tugas guru adalah: 1) merumuskan tujuan pembelajaran, 2) merencanakan kegiatan pembelajaran, 3) melaksanakan kegiatan pembelajaran sesuai tujuan dan rencana pembelajaran, 4 ) melakukan evaluasi pembelajaran sesuai dengan tujuan dan rencana pembelajaran, 5) melakukan pembaharuan, dan perbaikan hasil evaluasi.

Selanjutnya tanggung jawab guru berdasarkan observasi dan wawancara, secara umum, guru di Kabupaten Karawang mengetahui dan mengerti mengenai tanggung jawab sebagai guru sebagai berikut, yaitu bertanggung jawab kepada, lembaga pendidikan, orang tua siswa, pemeritah, masyarakat dan Tuhan Yang Maha Esa.

Berdasarkan hasil uraian tersebut dapat disimpulkan bahwa peran dan partisipasi guru dalam meningkatkan kualitas pendidikan di SMP di kabupaten Karawang secara umum guru dapat berperan dan berpartisipasi dalam meningkatkan pendidikan walau masih belum maksimal dikarenakan adanya keterbatasan berbagai sumberdaya yang meliputi tenaga, biaya, sarana dan fasilitas dan letak geografis.dan lebih jelasnya dapat dijelaskan dalam Gambar 1.

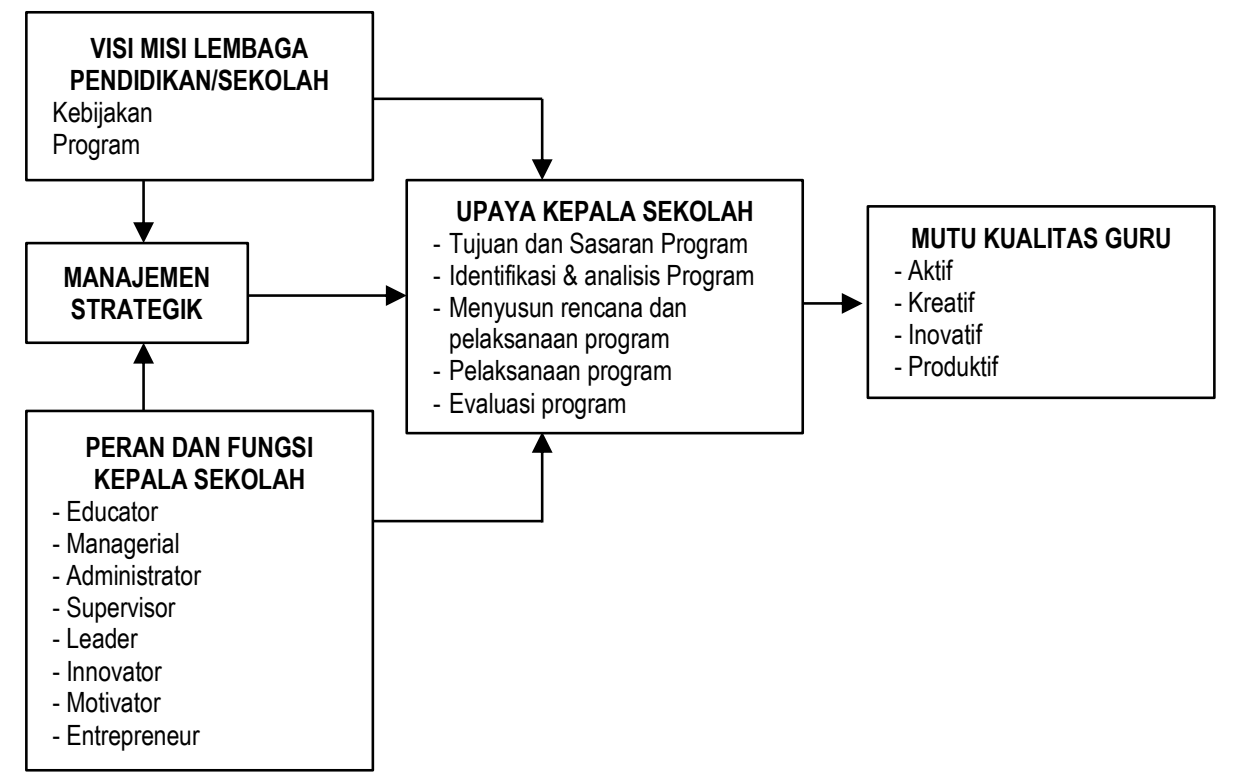

Gambar 1. Proses Manajemen Strategik Kepemimpinan Sekolah SMP dalam Meningkatkan Kualitas Guru

\section{SIMPULAN}

Peran dan fungsi pemimpin sekolah di SMP dalam meningkatkan kualitas guru di Kabupaten Karawang dapat berperan dan berfungsi karena secara umum setiap pemimpin sekolah dapat mengetahui dan memahami peran kepala sekolah yang sesuai dengan kompetensi kepala sekolah yaitu a) kompetensi meneger, b) kompetensi Kewirausahaan (entrepreneur), c) Kompetensi supervisi, d) kopetensi kepribadian dan e) Kompetensi sosial. Yang sesuai dengan Permendiknas 
No. 13 Tahun 2007 tentang Standar Kepala Sekolah/Madrasah, walau dalam pelaksanaan programnya masih terdapat hambatan yang disebabkan adanya keterbatasan sumberdaya yang dimiliki sekolah, yang meliputi sarana,fasilitas, dana, dan tenaga untuk penyelenggaraan pendidikan.

Upaya manajemen strategik kepemimipinan meningkatkan kualitas guru SMP di Kabupaten Karawang. Dapat dilakukan oleh pimpinan sekolah dengan melakukan cara koordinasi, komunikasi, integrasi, monitoring dan evaluasi seluruh program penyelenggaraan pendidikan, dengan langkah, langkah sebagai berikut a). mnentukan tujuan dan sasaran tujuan program, b) mengidentifikasi dan menanalisis, kebutuhan program, c) menyusun rencana pelaksanaan alternative program, d) melaksanakan alternatif program, dan e) evaluasi program.

Peran dan partisipasi guru dalam meningkatkan kualitas pendidikan di SMP di kabupaten Karawang secara umum guru dapat berperan dan berpartisipasi dalam meningkatkan pendidikan karena guru sebagaian besar dapat melaksanakan tugas dan kewajibannya, yaitu dapat melaksanakan program pembelajaran, walau masih belum maksimal dikarenakan adanya keterbatasan berbagai sumberdaya yang meliputi tenaga, biaya, sarana dan fasilitas dan letak geografis.

\section{REFERENSI}

Abduloh, A. (2015). Profil Pemimpin Pendidikan Masa Depan Islami yang Mampu Menghadapi Masalah Kompleks. MENDIDIK: Jurnal Kajian Pendidikan dan Pengajaran, 1(2), 171-190.

Artasasmita, R. (1985). Courses and practice. Bandung: FIP IKIP Bandung.

Bogdan, R., \& Taylor, S. J. (1993). Qualitative the Bottomside of Research. Surabaya: National Effort.

Bush, T. (2003). Theories of educational leadership and management. Sage.

Bush, T., \& Middlewood, D. (2013). Leading and managing people in education. Sage.

Cascio, W. F., \& Awad, E. M. (1981). Human Resources Management: An Information System Approach. Virginia: By Reston Publishing Company.

Depdikbud. (2000). Bulletin Pelangi Pendidikan. Jakarta. Depdikbud.

Dessler, G., Sutherland, G., \& Cole, N. D. (2005). Human resources management in Canada. Canada: Pearson Education Canada.

Fainstein, S. S., \& Campbell, S. (Eds.). (2002). Readings in urban theory. Wiley-Blackwell.

Gipps, C. V., \& Goldstein, H. (1983). Monitoring children: An evaluation of the Assessment of Performance Unit (Vol. 1). New Hampshire: Heinemann Educational Publishers.

Kydd, L. (2004). Pengembangan Propesional Untuk Manajemen Pendidikan (terjemahan Ursula Gyani B). Jakarta: Grasindo.

Masyud, M. S., \& Khusnurdilo, M. (2003). Manajemen Pondok Pesantren. Jakarta: Diva Pustaka.

Megalia, R., \& Makmun, A. S. (2017). Manajemen Peningkatan Kompetensi Aparatur (Studi tentang Implementasi Kebijakan Reformasi Sumber Daya Kediklatan pada Badan Diklat Kementerian Dalam Negeri RI). Jurnal Administrasi Pendidikan, 17(1), 127-144.

Mulyasa, E. (2007). Menjadi Kepala Sekolah Profesional. Bandung: Remaja Rosdakarya.

Nasution, S. (2004). Metode Research. Jakarta: Bumi Aksara.

Nazir, M. (2003). Metode Penelitian. Jakarta: Ghalia Indonesia.

Purwanto, N. (1984). Administrasi Pendidikan. Jakarta: Mutiara.

Sudjana, H. D. (2001). Manajemen Program Pendidikan. Bandung: Falah Production.

Sudjana, H. D. (2004). Manajemen Program Pendidikan. Bandung: Falah Production.

Triton, P. B. (2005). Paradigma Baru Manajemen Sumber Daya Manusia. Yogyakarta: Tugu Publisher. 